\title{
Peripheral arterial disease in antiretroviral therapy naïve HIV infected patients - an experience from eastern India
}

\author{
Dibbendhu Khanra ${ }^{*}$, Arunansu Talukdar', Manjari Saha ${ }^{1}$, Ashutosh Dey $^{2}$ \\ From 2nd International Science Symposium on HIV and Infectious Diseases (HIV SCIENCE 2014) \\ Chennai, India. 30 January - 1 February 2014
}

\section{Background}

HIV induced endothelial dysfunction leads to premature atherosclerosis which may manifest as peripheral arterial disease (PAD) of lower limbs. Studies are not available on prevalence of PAD among antiretroviral therapy (ART) naïve HIV infected population. Our objective was to explore the prevalence of PAD among HIV seropositive cases, and to determine relation of PAD with HIV infectivity and its correlation with CD4 count.

\section{Methods}

This hospital based cross sectional study included 100 consecutive newly diagnosed HIV seropositive ART naïve cases (age 20-49 years) and 100 age and sex matched HIV seronegative controls. PAD was diagnosed by Doppler study of lower limb arteries.

\section{Result}

Prevalence of PAD was significantly more among HIV infected cases $(71 \%)$ in comparison to HIV negative controls ( $\mathrm{p}<0.001)$. Among the cases of PAD, 53\% (38/71) patients were asymptomatic. Active tuberculosis was present in 25\% (18/71) of HIV infected PAD patients. The mean CD4 count among the HIV positive PAD cases was 220 cells/ dl. HIV sero-positivity was found to be independently contributing to development of PAD. Male gender, concurrent tuberculosis and low CD4 count came out to be individually contributing to PAD among HIV sero-positive cases in multivariate analysis.

\footnotetext{
* Correspondence: ddk3987@gmail.com

${ }^{1}$ Department of General Medicine, Medical College and Hospital, Kolkata, India

Full list of author information is available at the end of the article
}

\section{Conclusion}

Prevalence of symptomatic and asymptomatic PAD was high in the ART naïve HIV-infected cases of relatively younger age group. HIV infected patients should undergo evaluation for lower limb peripheral arterial diseases in appropriate background. Larger population based prospective study involving HIV seropositive patients would enlighten the temporal association of PAD and other cardiovascular morbidities.

\section{Authors' details}

${ }^{1}$ Department of General Medicine, Medical College and Hospital, Kolkata, India. 'Department of Radiodiagnosis, Medical College and Hospital, Kolkata, India.

Published: 27 May 2014

doi:10.1186/1471-2334-14-S3-P50

Cite this article as: Khanra et al:: Peripheral arterial disease in antiretroviral therapy naïve HIV infected patients - an experience from eastern India. BMC Infectious Diseases 2014 14(Suppl 3):P50.

Submit your next manuscript to BioMed Central and take full advantage of:

- Convenient online submission

- Thorough peer review

- No space constraints or color figure charges

- Immediate publication on acceptance

- Inclusion in PubMed, CAS, Scopus and Google Scholar

- Research which is freely available for redistribution 